Article

\title{
Development of 3D Hepatic Constructs Within Polysaccharide-Based Scaffolds with Tunable Properties
}

\author{
Marie-Noëlle Labour ${ }^{1,2,3}$, Camile Le Guilcher ${ }^{1,2}$, Rachida Aid-Launais ${ }^{1,4}$, Nour El Samad ${ }^{1,2}$, \\ Soraya Lanouar ${ }^{1,2}$, Teresa Simon-Yarza ${ }^{1,2}$ and Didier Letourneur $1,2, * \mathbb{D}$ \\ 1 INSERM U1148, LVTS, Université de Paris, X Bichat Hospital, 46 rue H Huchard, F-75018 Paris, France; \\ marie-noelle.labour@enscm.fr (M.-N.L.); camille.le-guilcher@inserm.fr (C.L.G.); \\ rachida.aid@inserm.fr (R.A.-L.); nourelsamad@hotmail.com (N.E.S.); soraya.lanouar@gmail.com (S.L.); \\ teresa.simon-yarza@inserm.fr (T.S.-Y.) \\ 2 INSERM U1148, LVTS, Université Sorbonne Paris Nord, 99 av JB Clément, 93430 Villetaneuse, France \\ 3 École Pratique des Hautes Études, Paris Sciences et Lettres (PSL) Research University, 4-14 rue Ferrus, \\ 75014 Paris, France \\ 4 INSERM UMS-34, FRIM Université de Paris, X Bichat School of Medicine, F-75018 Paris, France \\ * Correspondence: didier.letourneur@inserm.fr
}

Received: 19 April 2020; Accepted: 18 May 2020; Published: 21 May 2020

\begin{abstract}
Organoids production is a key tool for in vitro studies of physiopathological conditions, drug-induced toxicity assays, and for a potential use in regenerative medicine. Hence, it prompted studies on hepatic organoids and liver regeneration. Numerous attempts to produce hepatic constructs had often limited success due to a lack of viability or functionality. Moreover, most products could not be translated for clinical studies. The aim of this study was to develop functional and viable hepatic constructs using a 3D porous scaffold with an adjustable structure, devoid of any animal component, that could also be used as an in vivo implantable system. We used a combination of pharmaceutical grade pullulan and dextran with different porogen formulations to form crosslinked scaffolds with macroporosity ranging from $30 \mu \mathrm{m}$ to several hundreds of microns. Polysaccharide scaffolds were easy to prepare and to handle, and allowed confocal observations thanks to their transparency. A simple seeding method allowed a rapid impregnation of the scaffolds with HepG2 cells and a homogeneous cell distribution within the scaffolds. Cells were viable over seven days and form spheroids of various geometries and sizes. Cells in 3D express hepatic markers albumin, HNF4 $\alpha$ and CYP3A4, start to polarize and were sensitive to acetaminophen in a concentration-dependant manner. Therefore, this study depicts a proof of concept for organoid production in 3D scaffolds that could be prepared under GMP conditions for reliable drug-induced toxicity studies and for liver tissue engineering.
\end{abstract}

Keywords: 3D scaffold; tissue engineering; polysaccharide; organoid; liver; HepG2

\section{Introduction}

The liver is a vital organ with many crucial functions of detoxification, lipid and carbohydrate metabolism, homeostasis maintenance or blood protein synthesis. These functions can be impaired in many pathological conditions such hepatitis, cancer, genetic diseases or long term medication that induce liver fibrosis followed by cirrhosis which is irreversible and often leads to liver failure associated with poor prognosis. Cirrhosis and hepatocellular carcinoma are accountable for about $3.5 \%$ of deaths worldwide with an increasing prevalence [1]. Currently, allografts are the gold standard to treat end-stage liver diseases but, due to the lack of donors, tissue engineering strategies 
represent a promising therapeutic route for liver diseases [2-5]. Moreover, with the aim to reduce drug toxicity testing on animal models, tissue engineering platforms can be used as an efficient tool to reproduce liver architecture. Indeed, three-dimensional (3D) models have been extensively developed as an alternative to two-dimensional (2D) cell culture models that do not mimic complex tissues structures, and the benefits of 3D culture have been broadly demonstrated for a variety of cell types. Organoid biotechnologies emerged from the idea to recapitulate organogenesis and morphogenesis in order to create in vitro "organ on a chip" systems [6,7]. This technology is based on cell self-assembly, differentiation and production of extracellular matrix to produce a system mimicking organ structures. This strategy represents a highly valuable tool in particular for disease modeling. As hepatocytes rapidly lose their phenotype and specific functions when cultured in 2D [8-10], this approach has been largely investigated to improve in vitro models for drug-toxicity and liver diseases [11] or for tissue engineering applications including extracorporeal [11-14] or implantable devices to sustain liver functions during acute phases of diseases [5,15].

In the last decade, a variety of techniques have been developed or improved to produce functional hepatic organoids from self-assembly in microwells and microfluidic devices to hydrogels and additive manufacturing technologies [9,16-20]. Initially, sandwiched cultures promoted survival of functional primary hepatocytes and have been widely used since then [21,22]. Later on, spheroids were produced using different simple techniques such as culture on non-adherent plates, stirred plates or bioreactors [23-26], that offered spheroid mass production. To improve reproducibility and produce organoids with a homogeneous size, hanging-drop and emulsion-based techniques [19], as well as microwells made of non-adherent materials, were developed [18,27-29]. Some of these systems have led to product commercialization, for instance microwells Gri3D ${ }^{\mathrm{TM}}$ that can be used for different applications or preformed liver organoids 3D InSight ${ }^{\mathrm{TM}}$ Liver Microtissues. Importantly, hepatic organoid technology combined with microfluidic devices enabled high throughput screening for drug toxicity studies and improved in vitro models of liver fibrosis or tumor microenvironments [19,30,31]. Besides, Takebe et al. successfully implanted vascularized liver buds in mice of that sustain major liver functions [4]. However, drawbacks of these systems are the large diameter of the microtissues generated that could induce cell necrosis, the lack of functionality and most often the difficulty to manipulate these systems. To overcome these limitations, 3D scaffolds have been considered for hepatic organoid production. These scaffolds are frequently hydrogels made of natural materials as they exhibit soft mechanical properties similar to healthy liver [7,16,32-34]. The main constraint of 3D matrices for organoid studies are porosity and pore interconnectivity to allow cell infiltration and generation of organoids but also nutrients diffusion $[9,19,26]$. Matrigel, a protein mixture secreted by Engelbreth-Holm-Swarm mouse sarcoma cells, has been extensively used as support material for 3D cell culture, but it exhibits a low porosity and a high variability in terms of cell response, and cannot be clinically approved [10,35-37]. To favor cell-cell contacts and hence organoid formation, materials that do not present cell adhesion motifs are often used, in particular alginate-based matrices that promote hepatocyte spheroid formation by enhancing cell-cell interactions as well as hepatocellular activity such as albumin and urea production or detoxification functions $[33,36,38]$. All these systems are promising for the production of functional organoids but there is still a need to produce $3 \mathrm{D}$ scaffolds, easy to manipulate with a process that can be translated to the clinic with industrial processes. In addition, the 3D platforms should allow an easy loading of a high number of cells, have open and interconnected pores within the 3D structure for cell self-assembly, cell-cell contacts and matrix production while maintaining high cell viability.

The aim of our study was to produce 3D porous scaffolds with adjustable properties for viable and functional organoid development, allowing easy handling and observations. The challenges were to obtain highly porous structures that allow efficient cell loading and self-assembly into viable and functional organoids. In this context, we took the benefit of pullulan-dextran 3D porous matrices already used for in vitro and in vivo tissue engineering studies [39-42]. The main advantages of pullulan and dextran, two natural water-soluble polysaccharides already used in the food and 
pharmaceutical industry, are their biocompatibility and biodegradability. While dextran provides stability thanks to its high molecular weight, pullulan provides flexibility to the scaffold thanks to its branched polymeric structure. This combination produced a scaffold with soft and elastic mechanical properties easy to manipulate. These scaffolds have been used for a wide variety of applications such as vascular or bone tissue engineering [39,43-45] and their biodegradability is dependent on crosslinking ratio [46]. Moreover, they can be produced under GMP-conditions at large-scale and have been successfully implanted without major inflammatory reaction in mice, rats and goats $[39,43,47]$. The process for hydrogel formation relies on the addition of porogens during crosslinking using sodium trimetaphosphate (STMP) and freeze drying, a simple method to produce scaffolds easily at low cost and without any organic solvent. In this study, we describe for the first time the self-assembly of hepatic constructs in pullulan-dextran porous matrices. By varying porogen type and amounts, we have prepared several types of matrices and used HepG2 cell line as a model to investigate the effect of the formulation, and more particularly, the effect of porosity on cell clusters size and shape, cell viability and liver-specific functions.

\section{Results}

\subsection{Scaffold Preparation and Characterization}

The first objective of this study was to produce scaffolds to study the effect of different porosities on the viability and functionality of hepatic constructs. We used a patented method to create pullulan-dextran hydrogels based on the addition of porogens and a freeze-drying process [41,42]. A ratio 75:25 of high molecular weight Pullulan:Dextran has already been optimized to obtain easy-to-handle scaffolds [39-42]. In the present study, we investigated the effects of different amounts of two porogens, namely sodium chloride $(\mathrm{NaCl})$ and sodium carbonate $\left(\mathrm{Na}_{2} \mathrm{CO}_{3}\right)$ to obtain porous scaffolds that maximize cell loading and the diffusion of nutrients, oxygen and waste products. The limiting factor to increase porogen concentration is that polysaccharide solutions are very viscous. In the case of $\mathrm{NaCl}$, a maximum of $17 \%(w / w)$ of porogen could be added in the polysaccharide solution (Table 1). For $\mathrm{Na}_{2} \mathrm{CO}_{3}$, a maximum was reached at $15 \%$ w/w. At $18 \% \mathrm{Na}_{2} \mathrm{CO}_{3}$, although the solution appeared homogeneous, the procedure for scaffold molding was hindered by the too high viscosity (Table 1), and these scaffolds could not be obtained. Combined formulations with both $\mathrm{NaCl}$ and $\mathrm{Na}_{2} \mathrm{CO}_{3}$ were also prepared. With the combined formulations (ratio $\mathrm{NaCl}: \mathrm{Na}_{2} \mathrm{CO}_{3}$ 1:1), scaffolds with a total weight of $15 \%$ and $20 \%(w / w)$ could be obtained, and were named Combined-15 and Combined-20, respectively.

Physicochemical properties of the scaffolds were then analyzed. We studied phosphorous content that appraises crosslinking degree, swelling ratio and enzymatic degradation. Phosphorous content analysis revealed a significantly higher phosphorous content in $\mathrm{NaCl}$ scaffolds than in all other scaffolds suggesting a higher crosslinking ratio (Table 1). Swelling ratio was different for the five formulations, with Combined-20 scaffold being the highest. This observation implies that swelling does not depend primarily on phosphorous content since the latter was minimal for $\mathrm{Na}_{2} \mathrm{CO}_{3}-15$, maximal for $\mathrm{NaCl}$, and an intermediate value for Combined-20 scaffolds. Enzymatic degradation analysis revealed that scaffold degradation time is the longest in $\mathrm{NaCl}$ scaffolds which present the highest phosphorous content. For other formulations, where phosphorous content is similar, degradation $t_{1 / 2}$ decreases with an increasing amount of porogen (Table 1).

The macro- and micro-structures of the scaffolds after freeze-drying were analyzed by SEM to observe the internal porosity in dry state. Macroscopically, the structure of scaffolds formed with $\mathrm{NaCl}$ appears dense compared to all other formulations, where pores were even visible with the naked eye (Figure 1). The Combined-20 scaffold presents a distinctive cotton-like structure. SEM observations demonstrate that all dry scaffolds possess an open structure with interconnected pores. $\mathrm{NaCl}$ scaffolds present a homogeneous pore size distribution of approximately $200 \mu \mathrm{m}$ and a circular shape. In contrast, $\mathrm{Na}_{2} \mathrm{CO}_{3}-10$ scaffolds present two types of porosity: (i) small pores similar in shape to the ones obtained 
with $\mathrm{NaCl}$ alone and (ii) more elongated pores (width $\approx 200 \mu \mathrm{m}$, length $\approx 1 \mathrm{~mm}$ ), likely created by $\mathrm{CO}_{2}$ release in the washing acidic step. In $\mathrm{Na}_{2} \mathrm{CO}_{3}-15$ scaffolds, we mainly observed very large pores of about $500 \mu \mathrm{m}$ with irregular sizes. Thus, a mix of large elongated and small pores was obtained for combined scaffolds with the sizes increasing as the porogen concentration increases (Figure 1).

Table 1. Effect of polysaccharide formulations (porogen type and weight amounts) on scaffold production, phosphorous content $(n=3)$, swelling ratio $(n>6)$ and in vitro enzymatic degradation $\left(t_{1 / 2}\right.$, time to degrade $50 \%$ of the scaffold weight). Statistical analysis using student $t$-test. ${ }^{*} p<0.05$, ${ }^{* *} p<0.01,{ }^{* * *} p<0.001$ denote statistical significance against $\mathrm{NaCl}$ scaffold. ${ }^{\# \#} p<0.01,{ }^{\# \#} p<0.001$ denote statistical significance against all other scaffolds.

\begin{tabular}{|c|c|c|c|c|c|c|c|}
\hline Porogen & $\begin{array}{c}\text { Total } \\
\text { Porogen } \\
\% \\
\end{array}$ & $\begin{array}{l}\text { Solution } \\
\text { Viscosity }\end{array}$ & $\begin{array}{c}\text { Scaffold } \\
\text { Name }\end{array}$ & $\begin{array}{c}\text { Phosphorous } \\
\text { Content } \\
\mu M / g\end{array}$ & $\begin{array}{c}\text { Swelling } \\
\text { Ratio }\end{array}$ & & $\begin{array}{c}\text { Degradation } \\
t_{1 / 2} \\
\text { min }\end{array}$ \\
\hline \multirow{2}{*}{$\mathrm{NaCl}$} & 17.0 & + & $\mathrm{NaCl}$ & $234.6 \pm 0.3$ & $12.6 \pm 0.7]$ & \multirow{2}{*}{ 7* } & $27.2 \pm 6.2$ \\
\hline & 23.0 & insoluble & - & - & - & & - \\
\hline \multirow{4}{*}{$\mathrm{Na}_{2} \mathrm{CO}_{3}$} & 10.7 & ++ & $\mathrm{Na}_{2} \mathrm{CO}_{3}-10$ & $208.1 \pm 3.2 * * *$ & $11.4 \pm 1.1$ & \multirow{2}{*}{$* * *$} & $18.5 \pm 4.8$ \\
\hline & 15.0 & +++ & $\mathrm{Na}_{2} \mathrm{CO}_{3}-15$ & $203 \pm 2.5^{* * *}$ & $13.4 \pm 1.1$ & & $14.6 \pm 0.7\rfloor$ \\
\hline & 18.8 & ++++ & - & - & - & \multirow{2}{*}{ * } & - \\
\hline & 25.3 & insoluble & - & - & - & & - \\
\hline \multirow{3}{*}{$\mathrm{NaCl}: \mathrm{Na}_{2} \mathrm{CO}_{3} \mathrm{1:1}$} & 15.0 & ++ & Combined-15 & $207.1 \pm 7.2 * *$ & $12.3 \pm 1.3]$ & & $16.9 \pm 2.5$ \\
\hline & 20.6 & +++ & Combined-20 & $208.7 \pm 2.5^{* * *}$ & $21 \pm 0.6$ & & $6.6 \pm 2.3(\# \#)$ \\
\hline & 25.3 & insoluble & - & - & - & & - \\
\hline
\end{tabular}
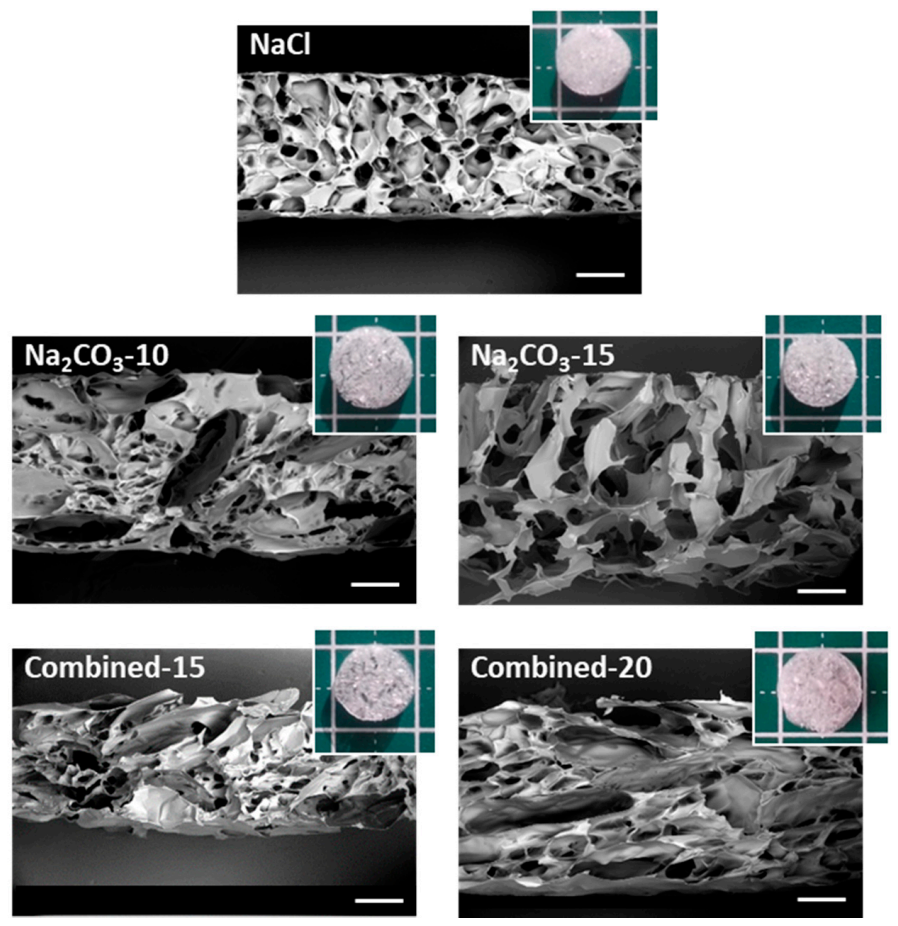

Figure 1. Macroscopic and microscopic (SEM) analysis of scaffold structures in dry state. Scaffolds for the five selected formulations were cut vertically to observe by SEM the inner structure under low vacuum mode $(40 \mathrm{~Pa})$ at a $20-\mathrm{kV}$ acceleration voltage. Scale bars on SEM pictures are $500 \mu \mathrm{m}$. Five representative dry scaffolds placed on a $1 \times 1 \mathrm{~cm}$ mat are shown in inserts. 
The microscopic structures of hydrated scaffolds were analyzed using 1\% FITC-dextran included in the initial formulations. Upon scaffold hydration in PBS, polysaccharide scaffolds immediately retracted due to hygroscopic properties of polysaccharides and then swelled within less than a minute, and produced transparent hydrogels. All scaffolds were easy to handle, soft and cohesive. Upon hydration, all pore sizes appear slightly smaller than the dry scaffolds but present a similar shape (Figure 2a). Scaffolds prepared with $\mathrm{NaCl}$ exhibited ovoid pores of about $200 \mu \mathrm{m}$ in length and about $30 \mu \mathrm{m}$ in width, whereas scaffolds with $\mathrm{Na}_{2} \mathrm{CO}_{3}$ presented more elongated pores between $0.5-1 \mathrm{~mm}$ length and widths ranging from 30 and $150 \mu \mathrm{m}$. In hydrated $\mathrm{Na}_{2} \mathrm{CO}_{3}$ scaffolds, we did not notice the smaller pores as observed in $\mathrm{NaCl}$ scaffolds. Regarding combined scaffolds, both types of porosity were observed: (i) small and ovoid; (ii) thin and elongated pores. Elongated pores in combined scaffolds were less present than in $\mathrm{Na}_{2} \mathrm{CO}_{3}$ scaffolds and had widths $(30-60 \mu \mathrm{m})$ lower than in $\mathrm{Na}_{2} \mathrm{CO}_{3}$ scaffolds. Smaller pores appeared similar to $\mathrm{NaCl}$ scaffolds although they presented a larger distribution in terms of size and geometry. No obvious difference was noted when increasing porogen concentrations. The percentage of porosity in volume was analyzed quantitatively in 3D stacks. For $\mathrm{NaCl}$ scaffolds, total porosity was about $30 \%$ whereas for all other conditions, porosity was about $40-50 \%$ (Figure 2 b). All porous scaffolds presented a high interconnectivity of pores within the entire 3D structures.

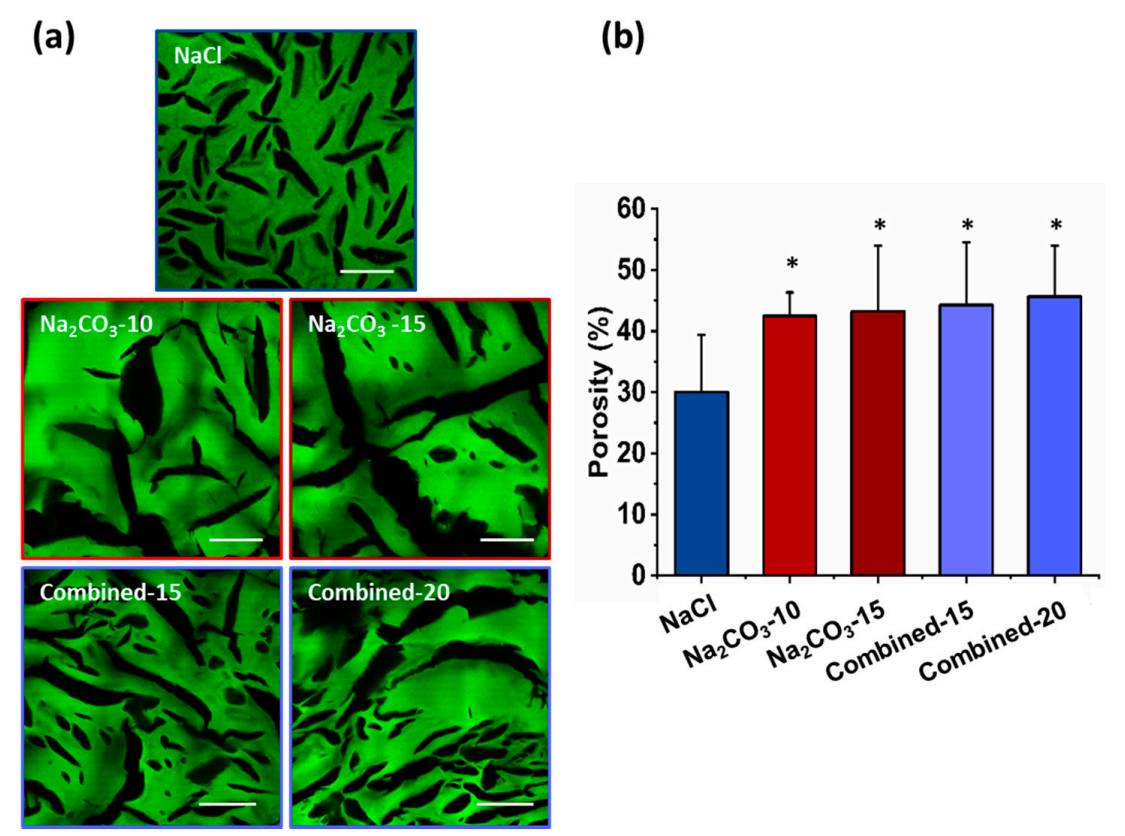

Figure 2. Hydrogels' porosity after hydration. (a) Representative confocal microscopy images of the different scaffolds containing Dextran-FITC. Scale bar $200 \mu \mathrm{m}$. (b) Scaffolds' porosity calculated from confocal stacks images in A. Statistics were performed using student $t$-test. Only $\mathrm{NaCl}$ scaffold porosity was significantly different than every other one. ${ }^{*} p<0.05, n=6$.

\subsection{Cell Cluster Size and Geometry}

Next, we investigated whether a change of porosity would modify geometry and size of cell clusters, and hence influence cell self-assembly, viability and functionality [17,26,29]. Indeed, to form viable and functional organoids in a 3D scaffold, one main factor is cell cluster size to allow nutrients and oxygen diffusion to the cells in the center of the construct, a critical feature for hepatic cells that requires high concentrations in glucose. Therefore, HepG2 cells were observed in the different scaffolds after seven days, stained for phalloidin and DAPI and imaged by confocal microscopy to observe cell clusters. We could see that cells were successfully loaded in all the scaffolds with a homogeneous distribution throughout the entire hydrogel. In $\mathrm{NaCl}$ scaffolds, where pores were small and ovoid, cell clusters appear small and circular, and they did not colonize the entire volume of the pores (Figure 3a top panel). Size analysis revealed a majority of small cell clusters with a median volume of $72.1 \mu^{3}$, 
i.e., about $52 \mu \mathrm{m}$ in diameter if considered as spherical (Figure 3a,b). In $\mathrm{NaCl}$ scaffolds, only $4.4 \%$ of cell clusters presented a diameter above $100 \mu \mathrm{m}$, a threshold considered as the maximum size for hepatic organoids [26,29]. On the contrary, in $\mathrm{Na}_{2} \mathrm{CO}_{3}$ scaffolds, cells filled up the pores generating thin and elongated cell clusters (Figure 3a middle panel) with a broader range of sizes due to the presence of both large and thin pores generated by $\mathrm{CO}_{2}$ release. Median volumes for $\mathrm{Na}_{2} \mathrm{CO}_{3}-10$ and $\mathrm{Na}_{2} \mathrm{CO}_{3}-15$ scaffolds were, respectively, 114.9 and $114.6 \mu^{3}$ (Figure 3b). In the combined scaffolds, distribution profiles of cell cluster volumes were similar to the distribution observed within $\mathrm{NaCl}$ scaffolds although volume distributions were slightly more heterogeneous (Figure 3a-c), likely due to the presence of a small number of large and thin pores generated by $\mathrm{CO}_{2}$ release. Cell cluster median volumes were $55 \mu \mathrm{m}^{3}$ for Combined-15 scaffolds, and $56.1 \mu \mathrm{m}^{3}$ for Combined-20 scaffolds (about $47 \mu \mathrm{m}$ diameter if considered spherical), but appear less spherical in the gel depth (z-direction) (Figure 3c). We noticed that the cells organized in spherical aggregates in combined scaffolds did not fill completely the volume of pores while they filled up the large elongated pores in $\mathrm{Na}_{2} \mathrm{CO}_{3}$ scaffolds (Figure 3a).

(a)
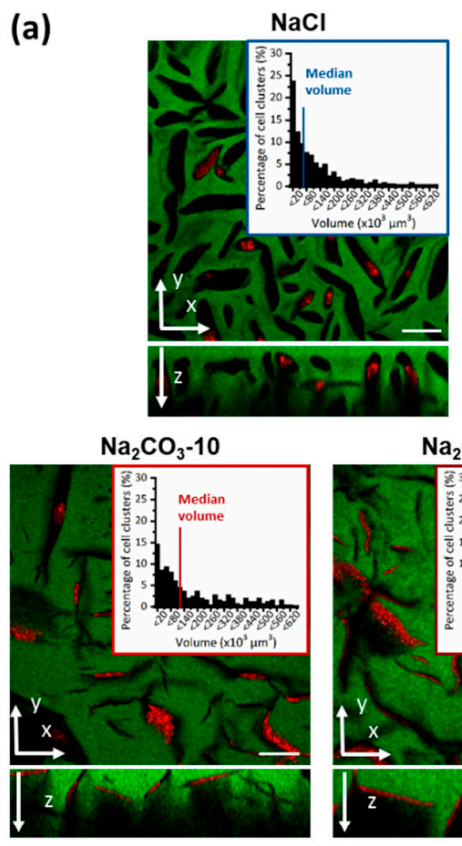

Combined-15

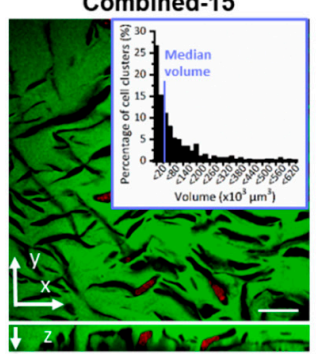

$\mathrm{Na}_{2} \mathrm{CO}_{3}-15$

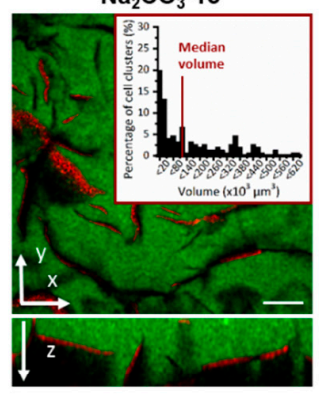

Combined-20

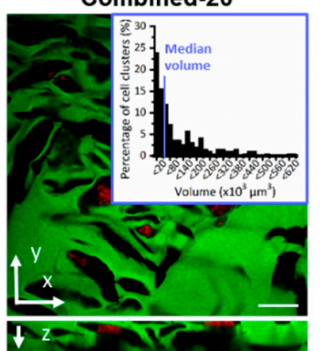

(b)

(c)
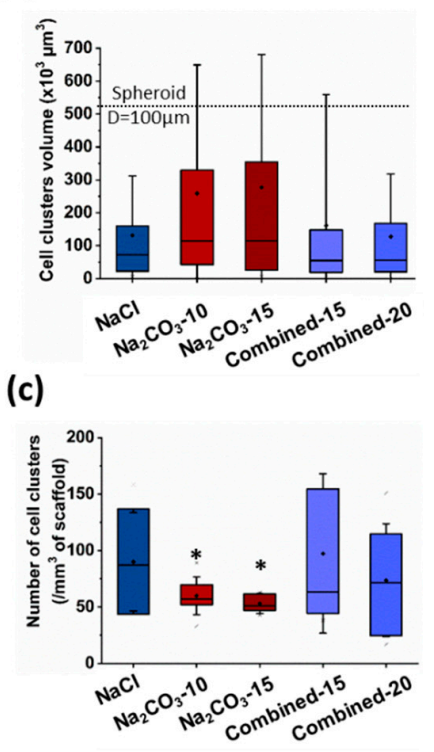

(d)

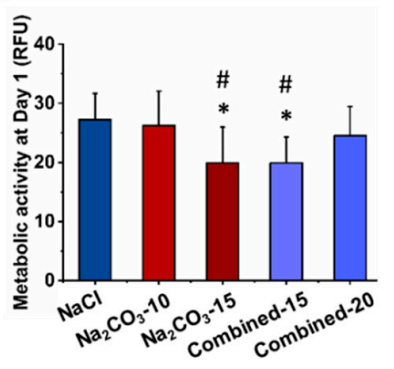

Figure 3. HepG2 cell clusters size and conformation in 3D scaffolds after seven days of culture. (a) Confocal image of the interior of scaffolds formed using $\mathrm{NaCl}$ (top panel), $\mathrm{Na}_{2} \mathrm{CO}_{3}$ (middle panel) or a combination of both porogens (bottom panel). Scaffolds were observed here in green due to $1 \%$ Dextran-FITC in the formulations. Cell clusters are shown using phalloidin-TRITC staining. Volume distribution of cell clusters (top right panels) formed within the scaffolds were determined using a 3D semi-automatic analysis using Imaris software. Scale bar: $200 \mu \mathrm{m}$. (b,c) Distribution of cell clusters volumes (b) and number of cell clusters per $\mathrm{mm}^{3}$ of scaffold (c) represented as box plot using median and 25-75 percentile. Mean volume is represented as a diamond-shape dot, error bars represent standard deviation. (d) Metabolic activity analysed at day one after seeding. Statistical analysis was performed using student $t$-test. * represent statistical difference towards $\mathrm{NaCl}$ scaffolds. ${ }^{*}$ represent statistical difference $(p<0.05)$ towards $\mathrm{Na}_{2} \mathrm{CO}_{3}-10$ scaffolds. All other differences were not significant. 
The number of clusters per $\mathrm{mm}^{3}$ was also evaluated and correlated with cell cluster volume (Figure 3b) as an index of loading efficiency and cell distribution within the scaffolds. As expected, the number of cell clusters per field of view was inversely proportional to cell cluster volume: a high number of cell clusters was detected within $\mathrm{NaCl}$ and Combined scaffolds, while the number was lower in $\mathrm{Na}_{2} \mathrm{CO}_{3}$ scaffolds (Figure 3c). To identify the scaffolds presenting the higher loading efficiency, the metabolic activity of cells in 3D was assessed $24 \mathrm{~h}$ after seeding (Figure 3d). This analysis demonstrated a slightly lower metabolic activity in $\mathrm{Na}_{2} \mathrm{CO}_{3}-15$ and Combined-15 than with other formulations, most likely due to, respectively, the presence of too large pores that do not retain cells and too small non-interconnected pores. Taken together, these results showed that two different types of scaffolds were formed, the first one formed with $\mathrm{NaCl}$ (or combined formulations) presented small and ovoid pores generating numerous small and spherical cell clusters, and the second type of scaffold with $\mathrm{Na}_{2} \mathrm{CO}_{3}$ exhibited thin and elongated pores producing cell clusters with similar elongated geometries. We therefore chose to compare for the following experiments cell viability and functionality in $\mathrm{NaCl}$ and $\mathrm{Na}_{2} \mathrm{CO}_{3}-10$ scaffolds that exhibited the two highest loading efficiencies and a clear difference in terms of cell cluster sizes and shapes.

\subsection{Cell Viability}

To assess the viability and proliferation capacity of HepG2 cells organized in small and spherical ( $\mathrm{NaCl}$ scaffolds) versus large and thin clusters $\left(\mathrm{Na}_{2} \mathrm{CO}_{3}-10\right)$, we analyzed overtime cell metabolic activity using a resazurin-based assay, and viability using a live-dead assay. To be noted, storage modulus measured by Dynamic Mechanical Analysis at $1 \mathrm{~Hz}$ in the viscoelastic linear domains were similar on $\mathrm{NaCl}$ and $\mathrm{Na}_{2} \mathrm{CO}_{3}-10$ scaffolds, respectively $5010 \pm 720 \mathrm{~Pa}$ and $4390 \pm 210 \mathrm{~Pa}$, implying that cell behavior could not be attributed to a difference in the mechanical rigidity of the scaffolds.

Metabolic activity was similar at day one for $\mathrm{NaCl}$ and $\mathrm{Na}_{2} \mathrm{CO}_{3}-10$ scaffolds (Figure 4a). In $\mathrm{NaCl}$ scaffolds, metabolic activity increased significantly from day one to day four and seven reaching a plateau, i.e., HepG2 cells stopped proliferating but remain viable. In $\mathrm{Na}_{2} \mathrm{CO}_{3}-10$ scaffolds, metabolic activity increased slightly but continuously over seven days. Therefore, cell proliferation was limited within both types of scaffolds but cells remain alive for at least seven days. After seven days of culture, no statistical difference was noted between these two scaffold formulations (Figure 4a). We analysed the cell viability using live-dead assay, especially in the gels depth where diffusion could be limited, and within clusters. The overall viability within the 3D hydrogels at day seven was $86.8 \pm 6.3 \%$ for $\mathrm{NaCl}$ scaffold and $90.5 \pm 5.9 \%$ in $\mathrm{Na}_{2} \mathrm{CO}_{3}-10$ scaffolds. Confocal images demonstrated that the live-dead ratio remained constant in the scaffold depth up to the maximum possible analysis at $300 \mu \mathrm{m}$ by confocal microscopy (Figure $4 \mathrm{~b}$ ) for both scaffolds. The homogeneous distribution of the cell clusters was evidenced within both scaffolds (Figure 4c). When zooming in on cell clusters, it appears that the visible dead cells were not located in the center of clusters, but they were often individualized isolated cells (Figure 4c, inserts). We hypothesized that individual cells did not survive because they cannot adhere to the scaffolds whereas they can live when forming a cell cluster. Hence, the viability was similar between small and spherical cell clusters ( $\mathrm{NaCl}$ scaffold) and in elongated and large clusters $\left(\mathrm{Na}_{2} \mathrm{CO}_{3}\right.$ scaffold), implying a sufficient diffusion of nutrients and oxygen. 
(a)

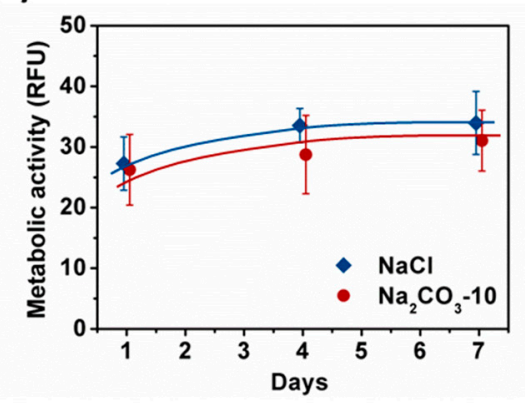

(c)

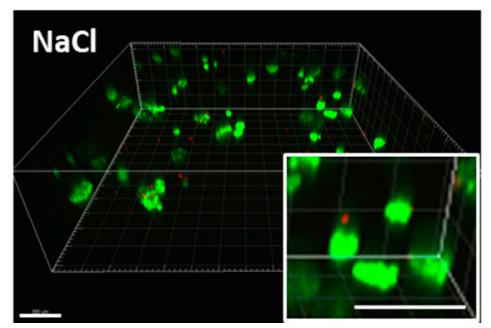

(b)
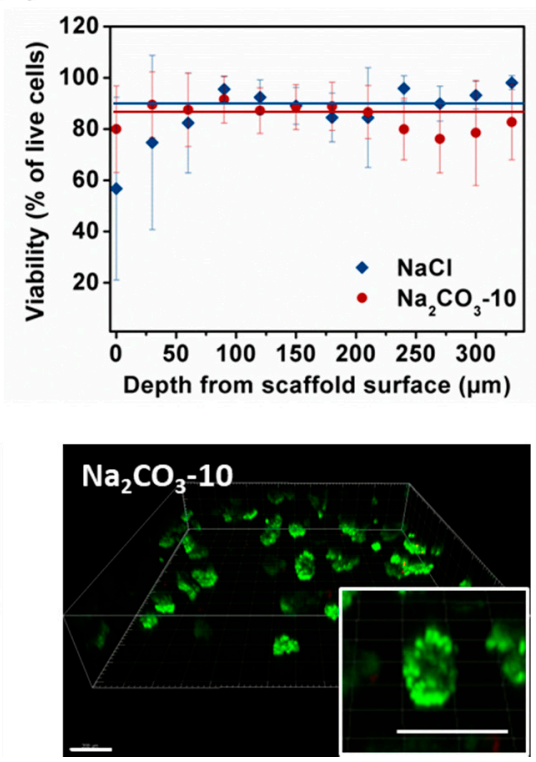

Figure 4. Analysis of HepG2 viability and metabolic activity over seven days within $\mathrm{NaCl}$ and $\mathrm{Na}_{2} \mathrm{CO}_{3}-10$ scaffolds. (a) Cell metabolic activity of HepG2 within $\mathrm{NaCl}$ (blue) and $\mathrm{Na}_{2} \mathrm{CO}_{3}-10$ (red) scaffolds at day one, four and seven. (b) Percentage of viable cell within $\mathrm{NaCl}$ and $\mathrm{Na}_{2} \mathrm{CO}_{3}-10$ scaffolds as function of distance from the scaffold surface at day seven. Statistics were performed using ANOVA with Tukey's post-test. No significant difference was observed. (c) Representative 3D images of live-dead analysis of $\mathrm{NaCl}$ (top panel) and $\mathrm{Na}_{2} \mathrm{CO}_{3}$ (bottom panel) scaffolds at day seven. Live cells were stained with Calcein AM (green) and dead cells are detected with Ethidium homodimer (red). Scale bar: $200 \mu \mathrm{m}$.

\subsection{Cell Functionality in Porous Scaffolds}

Apart from viability, size and geometry of cell clusters are known to modulate cell differentiation and hence organoid functionality $[26,29]$. Therefore, albumin secretion, CYP3A4 activity and expression of Albumin and HNF- $4 \alpha$ were analyzed as typical hepatic function markers. We quantified albumin secretion in cell culture supernatants after one, four and seven days. At day one, no statistical difference was observed between the two types of scaffolds, although the albumin quantity was slightly higher in $\mathrm{Na}_{2} \mathrm{CO}_{3}-10$ scaffold than $\mathrm{NaCl}$ scaffold (respectively $1.24 \pm 0.02$ and $0.74 \pm 0.38 \mu \mathrm{g} / \mathrm{mL} / 10^{6}$ cells). Albumin production increased overtime in both scaffolds to reach similar values at $1.80 \pm 0.28 \mu \mathrm{g} / \mathrm{mL} / 10^{6}$ cells in $\mathrm{Na}_{2} \mathrm{CO}_{3}-10$ scaffolds and $1.81 \pm 0.6 \mu \mathrm{g} / \mathrm{mL} / 10^{6}$ cells in $\mathrm{NaCl}$ scaffolds at day seven (Figure $5 \mathrm{a}$ ). These albumin concentrations are in agreement with several others studies using HepG2 cells [48-50]. CYP3A4 activity (Figure $5 b$ ) exhibited a profile inversely proportional to albumin secretion, also in agreement with the literature [51-53]. In line with these data, we also observed cytoplasmic expression of albumin in HepG2 cells within both types of scaffolds, and nuclear expression of HNF- $4 \alpha$ in most cells at day seven (Figure 5c). Moreover, phalloidin staining revealed actin aggregates bounded by HepG2 cells (Figure 5d), a phenomenon coinciding with the development of bile canaliculi [54-57]. To further confirm that these cell clusters were functional, we performed a dose-response analysis of acetaminophen toxicity in the 3D constructs (Figure 5e). In both $\mathrm{NaCl}$ and $\mathrm{Na}_{2} \mathrm{CO}_{3}-10$ scaffolds, HepG2 cells were sensitive to increasing concentrations of acetaminophen with $\mathrm{EC}_{50}$ of 67.70 and $67.75 \mathrm{mM}$, respectively. As acetaminophen is catalyzed by CYP3A4 to a toxic intermediate, this suggests that 3D constructs in both scaffolds have an active and functional CYP3A4 and were able to detect liver toxic compounds. Overall, these data demonstrate that cell clusters formed in 3D scaffolds present the main characteristics required for hepatic constructs. 
(a)

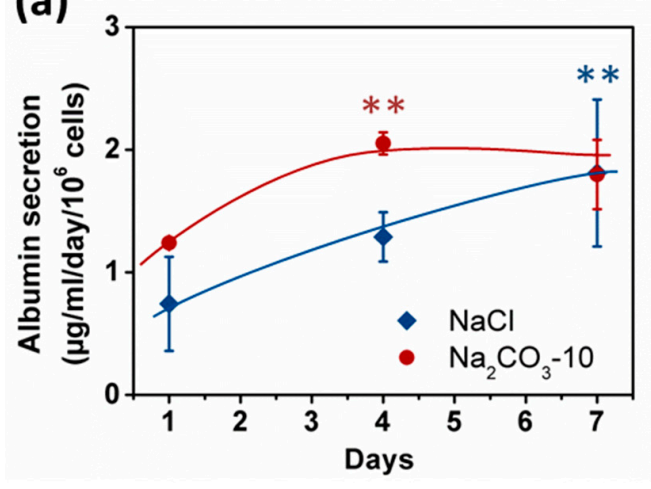

(c)
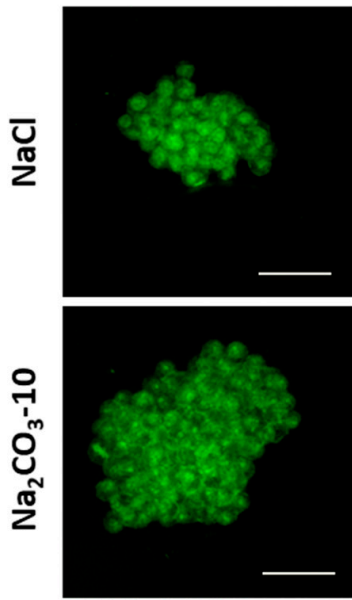

Nucleus (Syto13)

(d)

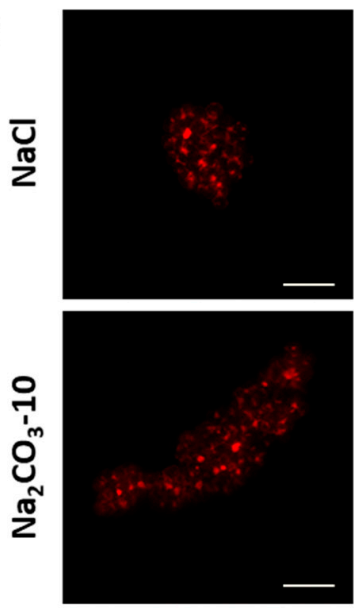

Phalloidin
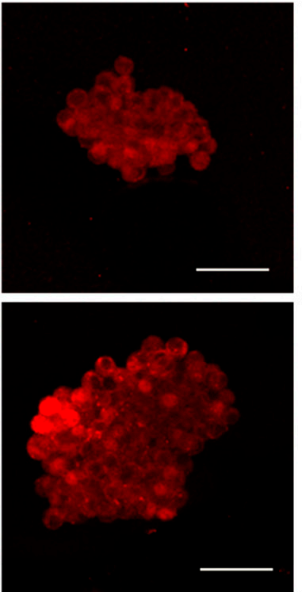

Albumin
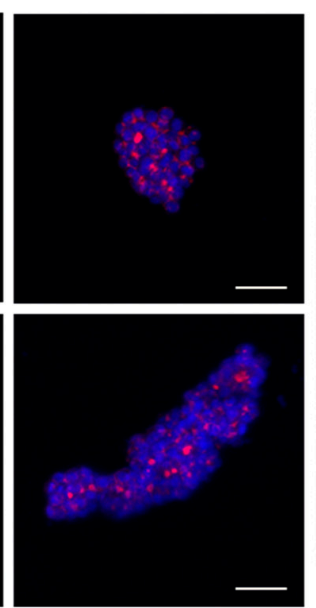

Phalloidin DAPI (b)
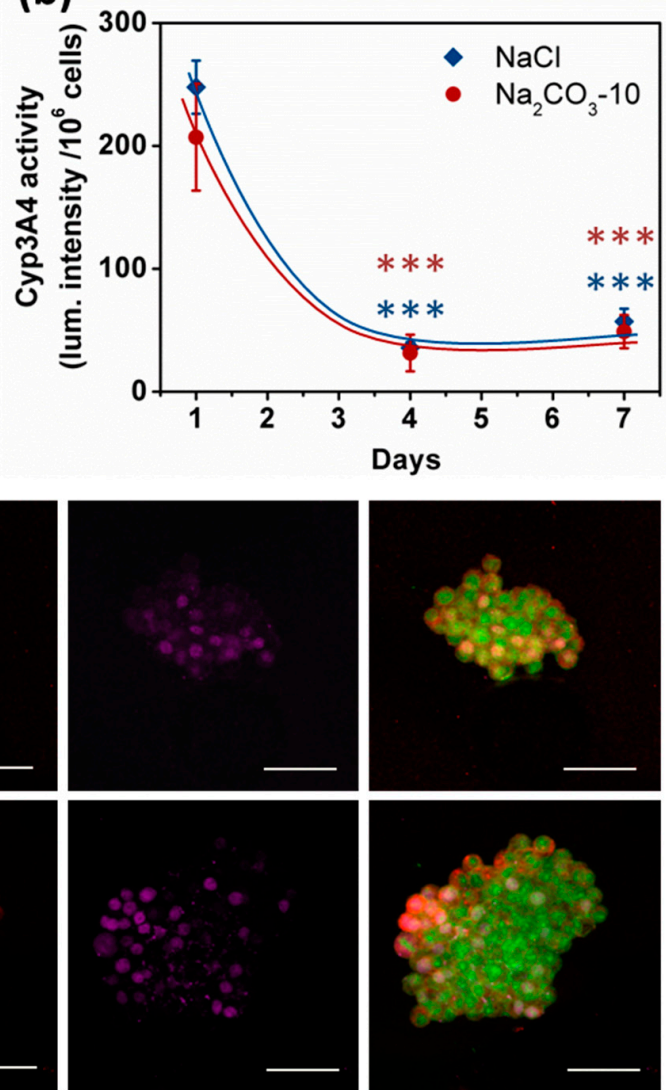

HNF4a

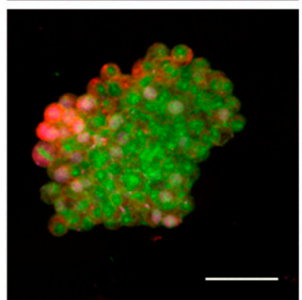

Merge
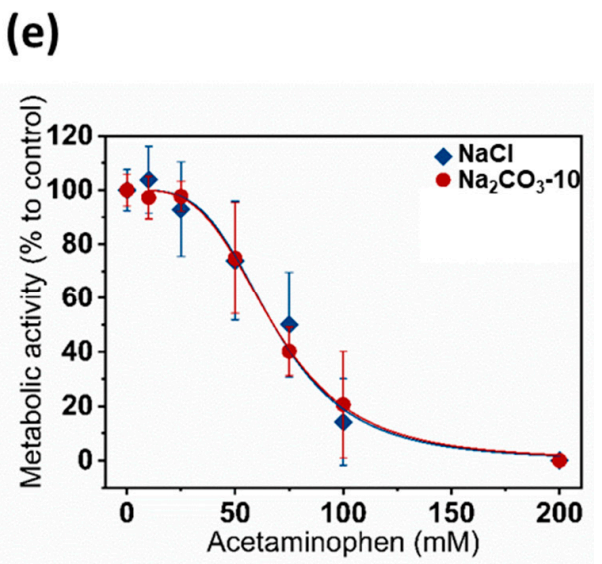

Figure 5. HepG2 cell functionality in 3D within $\mathrm{NaCl}$ and $\mathrm{Na}_{2} \mathrm{CO}_{3}-10$ scaffolds. (a) Quantification of albumin secretion in the medium for $24 \mathrm{~h}$ after one, four and seven days using ELISA. (b) Quantification of P450 cytochrome CYP3A4 activity overtime. (c) Confocal images (Maximum intensity projection) of typical cell clusters showing the expression of Albumin (red) in the cytoplasm and HNF4 $\alpha$ (purple) localized in the nucleus for scaffolds prepared with $\mathrm{NaCl}$ (top panel, 30 $\mu \mathrm{m}$ total thickness) and $\mathrm{Na}_{2} \mathrm{CO}_{3}-10$ (bottom panel, $80 \mu \mathrm{m}$ total thickness) at day seven. (d) Confocal images at day seven (Maximum intensity projection) of typical cell clusters showing the aggregation of Actin (red) in between cells for scaffolds prepared with $\mathrm{NaCl}$ (top panel, $49 \mu \mathrm{m}$ total thickness) and $\mathrm{Na}_{2} \mathrm{CO}_{3}-10$ (bottom panel, $94 \mu \mathrm{m}$ total thickness). (e) Acetaminophen-induced toxicity at day seven on HepG2 cells after $24 \mathrm{~h}$ treatment in $\mathrm{NaCl}$ and $\mathrm{Na}_{2} \mathrm{CO}_{3}-10$ scaffolds. Scale bars: $50 \mu \mathrm{m}$. Statistical analysis was performed using ANOVA with Tukey's post-test. ${ }^{* *} p<0.01,{ }^{* * *} p<0.001$. 


\section{Discussion}

The main goal of this study was to analyze the effect of sizes and geometries of hepatic constructs on cell functionality using porous scaffolds. Scaffolds were prepared by cross-linking of polysaccharides in the presence of different porogen agents $\left(\mathrm{NaCl}\right.$ or $\left.\mathrm{Na}_{2} \mathrm{CO}_{3}\right)$ to obtain various microstructures of different sizes and geometries. These scaffolds made of polysaccharides are easy to produce and to handle. They are transparent, allowing direct microscopic observation, and they can be stored at room temperature long term before use. We used a patented technique based on the combination of porogen addition and freeze drying process [41,42]. Concentrated solutions of high molecular weight polysaccharide solutions being very viscous; a maximum of $20 \%(w / w)$ of porogen could be added to the polysaccharide solution (Table 1). Scaffolds formed with $\mathrm{NaCl}$ presented small and ovoid pores originating from ice crystal formation during the freeze drying process [58,59]. In both $\mathrm{Na}_{2} \mathrm{CO}_{3}$ and Combined scaffolds $\left(\mathrm{NaCl}+\mathrm{Na}_{2} \mathrm{CO}_{3}\right)$, two types of porosity were observed: large and very thin pores coming from the release of $\mathrm{CO}_{2}$ after crosslinking $[60,61]$ and smaller pores arising from the freeze-drying step. The small pores displayed in $\mathrm{Na}_{2} \mathrm{CO}_{3}$ were not visible after hydration, most likely due to polymer swelling in water. Indeed, these scaffolds absorb more than 10 times their weight in water (Table 1), but their total volume decrease by a factor of about 2.8 times. This suggests a high swelling of polysaccharide chains thereby concealing the small pores. In Combined-20 scaffolds compared to $\mathrm{Na}_{2} \mathrm{CO}_{3}-10$ scaffolds, which both contain the same amount of $\mathrm{Na}_{2} \mathrm{CO}_{3}$, we observed a higher number of small pores and a lower number of thin elongated pores. Hence, the presence of $\mathrm{NaCl}$ in the initial solution affect pore formation in $\mathrm{Na}_{2} \mathrm{CO}_{3}$ scaffolds.

The percentage of porosity between $30 \%$ and $50 \%$ and pore geometry of all scaffolds appear adapted for cell loading and infiltration. Besides, recent results also suggest that there is also nanoporosity that will allow nutrients and oxygen diffusion [59] which is not observable by confocal microscopy because of its technical limitations. The increase in porogen amount increases slightly but not significantly the total porosity of scaffolds. Upon immersion in PBS, the polysaccharide chains swelling in the center of the scaffolds fill in the pores. Therefore, the increase in pore size due to the increase in porogen amount is partially masked by the swelling of polymer chains. Phosphorous content analysis showed that phosphorous amount was higher in $\mathrm{NaCl}$ scaffolds than in all other formulations. Even though phosphorous is not strictly instructive on the effective bounds between two polysaccharide chains, i.e., crosslinking density, previous studies have shown that the mesh size calculated from phosphorous amount correlate with rheological behavior [46,59] and therefore can be used to appraise crosslink ratio. Although STMP crosslinking reaction is still not fully understood in such a complex system, we know that the STMP-mediated formation of phosphorous bound between hydroxyl groups in alkaline solution brings into play different mechanisms. Polysaccharides diluted in alkaline solution result in immediate alcoholate formation that can attack and open STMP resulting in polysaccharide-bound sodium tripolyphosphate. Next, another alcoholate can attack polysaccharide-bound sodium tripolyphosphate creating a phosphoester bond between two saccharide units. However, alcoholate attacks on phosphorous links are in competition with $\mathrm{NaOH}$, suggesting that crosslinking reaction is very sensitive to $\mathrm{pH}[62,63]$. We hypothesized that the presence of $\mathrm{Na}_{2} \mathrm{CO}_{3}$ in the starting polysaccharide solution, modulates osmotic pressure and therefore affects crosslinking reactions. This would explain the significantly higher phosphorous content observed for $\mathrm{NaCl}$ scaffolds compared to all other formulations. Swelling ratio and degradation time was increased when increasing porogen amount, especially for Combined-20 scaffolds. The biphasic in vitro degradation pattern of these scaffolds demonstrates that different factors govern enzymatic degradation rates. Firstly, the scaffold porosity is a major factor determining degradation rate because of enzyme diffusion and provided surface area. The lower porosity of $\mathrm{NaCl}$ scaffolds can explain the slow degradation compared to all others scaffolds. However, $\mathrm{Na}_{2} \mathrm{CO}_{3}$ and Combined scaffolds present a similar porosity but different degradation times. Although the surface area was not quantified in this study, the presence of small pores in Combined scaffolds compared to $\mathrm{Na}_{2} \mathrm{CO}_{3}$ scaffolds likely increases surface area and therefore degradation rate. A second parameter is the availability of 
enzyme-binding motifs in the polysaccharide chains, influenced particularly by ionic interactions such as phosphate groups. Consequently, the less porous and more crosslinked scaffolds $(\mathrm{NaCl})$ present a slower degradation rate, whereas the more porous scaffolds, presenting a large surface area, are degraded faster.

When HepG2 cells were seeded, we observed that cells were viable within all formulations of polysaccharide scaffolds forming various cell clusters geometries. The biophysical characteristics of 3D scaffolds highly influence cell behavior in terms of adhesion, viability, proliferation and functionality $[64,65]$. In the particular case of organoids in hydrogels that do not promote cell adhesion, cells spontaneously self-organize and therefore porosity-which controls the number of cells in a confined space-is an essential characteristic that dictates cell behavior [38,66]. Cell loading/infiltration is also the crucial initial step that will influence the performance of a 3D scaffold to support organoid development. In this study, dry scaffolds could be easily impregnated with a cell suspension, thanks to the hygroscopic properties of polysaccharides and pore interconnectivity. Moreover, cells were uniformly distributed, which is essential for future applications in tissue engineering. A higher cell loading was observed in $\mathrm{NaCl}$ scaffolds which correlated with small pores and a high swelling ratio. Besides, the large pores and more open surfaces observed in $\mathrm{Na}_{2} \mathrm{CO}_{3}$ or Combined scaffolds can explain the lower cell retention in the scaffolds and the variability of cell clusters sizes. HepG2 cells remain viable equally in all scaffolds for more than a week. Considering a doubling time of $48 \mathrm{~h}$ for this cell line on usual 2D substrates, proliferation is moderate in the 3D scaffolds, probably owing to an efficient cell loading and lack of available space but also because cells do not adhere to the scaffold surface. Moreover, formation of cell spheroids might reduce proliferation, since cells engage mostly in matrix production [66]. Therefore, the limited proliferation is not detrimental when considering the application of these scaffolds for organoid production with different cell types such as primary hepatocytes or differentiated hepatocytes from iPS which do not proliferate.

After seven days in culture, we demonstrated that cell clusters sizes match pore size and shape. We observed a noticeable difference of cell clusters size between the scaffolds produced using $\mathrm{Na}_{2} \mathrm{CO}_{3}$ where cell clusters are large compared to the other formulations displaying a majority of smaller clusters. This observation correlates with the presence of small pores in combined scaffolds. In contrast, increasing porogen amount did not result in a significant change of scaffold porosity nor cell clusters sizes. In organoids, cells usually experience mass transfer limitations because of the absence of a vascular network $[6,11,20]$. It was previously demonstrated that primary hepatocytes viability exponentially decreased at the center of spheroids of about 100-150 $\mu \mathrm{m}$ to the spheroid surface due a decrease in oxygen [26,67-69]. In our study, more than $80 \%$ of hepatic constructs present a size lower than $100 \mu \mathrm{m}$ in diameter if considering a spherical shape. Moreover, since the largest constructs present ovoid shapes, the volume is not a limitation to cell viability, as the maximum distance of cells located in the center of organoids are only a few cells away from the medium. Interestingly, viability was not impaired when HepG2 cells fill up pores completely. This possibly relates to the appropriate diffusion of oxygen and nutrients within the polysaccharide network. Indeed, diffusion coefficients of oxygen in hydrogels are dependent on the polymer concentration/density but remain in the same order of magnitude than diffusion in water about $10^{-9} \mathrm{~m}^{2} / \mathrm{s}$ [70-72]. Larger molecules such as glucose or albumin exhibit lower diffusivity with coefficients expected to be about $10^{-10}$ to $10^{-11} \mathrm{~m}^{2} / \mathrm{s}$ if we consider that cell consumption is negligible [70]. Therefore, all types of scaffolds seem adapted for the development of viable small 3D cell constructs. Moreover, dynamic mechanical analysis revealed that scaffold elasticity is in the order of magnitude of elasticity of physiologic livers (4 kPa) [73-76].

HepG2 constructs in $\mathrm{NaCl}$ and $\mathrm{Na}_{2} \mathrm{CO}_{3}$ scaffolds differentiate and show specific functions of hepatocytes, such as expression of $\mathrm{HNF} 4 \alpha$, production of albumin and CYP3A4 activity. Hepatic constructs from both scaffolds demonstrate a profile of albumin secretion inversely proportional to CYP34A, in agreement with data from the literature [51,52]. We found a low CYP3A4 activity of HepG2 constructs in our scaffolds similar to the limited activity observed for small size cell spheroids of less than $200 \mu \mathrm{m}$ [66]. For larger HepG2 spheroids, hypoxic areas in HepG2 3D constructs 
increases in the core and subsequently increases CYP3A4 activity [53]. In our study, no hypoxia or cell death was observed in 3D constructs which could explain the reduced activity of CYP3A4 overtime. Moreover, an acetaminophen-induced cytotoxicity assay demonstrated that HepG2 cells are sensitive in a concentration-dependent fashion. CYP3A4 activities are responsible of $30 \%$ to $50 \%$ metabolism of medications by the P450 system in humans [77], including acetaminophen, the most common used analgesic antipyretic agent and the major cause of toxic liver injury in Western countries. In addition, the presence of actin condensation between HepG2 cells suggest that the cells polarize to form bile canaliculi [54-57]. Although some of the structures observed appear as vacuoles, some canaliculi are connected therefore indicating cell clusters organization and early signs of polarization.

Therefore, our data suggest that hepatic constructs formed in both $\mathrm{NaCl}$ and $\mathrm{Na}_{2} \mathrm{CO}_{3}$ scaffolds are viable and functional. As polysaccharide hydrogels are easily adjustable in terms of microstructures and surface properties [40,46,47], these scaffolds are very promising for drug-toxicity studies but also for liver regenerative medicine as they can be GMP produced. Moreover, this platform can be adapted for other types of organoids with single or multiple cell types. This study is a first proof a concept for the use of these scaffolds in cell-self-assembly. Future works will be needed with more suitable cell types and to confirm these results in vitro and in vivo for hepatic organoid production and long-term viability and functionality.

\section{Materials and Methods}

\subsection{Preparation of Scaffolds}

Polysaccharide-based scaffolds were prepared as described in [41,42]. Briefly, a mixture of pullulan (Hayashibara Co., Ltd., Okayama japan; Mw 200 kDa) and dextran (Pharmacosmos, Holbaeck, Denmark; $\mathrm{Mw} 500 \mathrm{kDa}$ ) with a ratio 75:25 was prepared in water. Sodium chloride $(\mathrm{NaCl})$ and/or sodium carbonate $\left(\mathrm{Na}_{2} \mathrm{CO}_{3}\right)$ were added to the polysaccharide solution (Table 1). The polysaccharide blend was crosslinked under alkaline conditions (1 M sodium hydroxide) using 3\% (w/v) STMP (Sigma) and casted between two glass plates before incubation at $50{ }^{\circ} \mathrm{C}$ for $20 \mathrm{~min}$. The resulting gels were punched in wet state to obtain $5 \mathrm{~mm}$ diameter and $1 \mathrm{~mm}$ thick scaffolds that were equilibrated to neutral $\mathrm{pH}$ using 10× PBS and washed extensively with distilled water for at least $24 \mathrm{~h}$ to remove the porogen agent and the excess of salts. When $\mathrm{Na}_{2} \mathrm{CO}_{3}$ was used, scaffolds were firstly transferred into $20 \%$ acetic acid to allow $\mathrm{CO}_{2}$ gas release before neutralization and rinsing. All scaffolds were freeze-dried in water or $\mathrm{NaCl} 0.025 \%(w / v)$ for the scaffolds with $\mathrm{NaCl}$ and stored at room temperature until use. The solubility and scaffold formation was evaluated with increasing quantities of porogens. For porosity analysis, $1 \%$ fluorescein isothiocyanate (FITC)-labeled dextran $500 \mathrm{kDa}$ (TdB Consultancy, Uppsala, Sweden) was added to the polymer solution before crosslinking.

\subsection{Characterization of Biophysical Properties of Scaffolds}

\subsubsection{Phosphorous Content Analysis}

About $20 \mathrm{mg}$ of each scaffold were degraded with $1 \mathrm{~mL}$ of $10 \%$ nitric acid and incubated at $105^{\circ} \mathrm{C}$ for $3 \mathrm{~h}$. Subsequently, $0.4 \mathrm{~mL}$ of $14.7 \mathrm{M}$ nitric acid, $2 \mathrm{~mL}$ of $10 \mathrm{mM}$ ammonium metavanadate, and $2 \mathrm{~mL}$ of $40 \mu \mathrm{M}$ ammonium molybdate tetrahydrate were added into each sample. Phosphorous ions concentration was then determined by spectrophotometry at $405 \mathrm{~nm}$ using a phosphoric acid standard curve. Samples were run in triplicates and results were expressed as mean values \pm SD.

\subsubsection{Swelling Behavior of the Scaffolds}

Scaffolds were weighed before $\left(\mathrm{w}_{\mathrm{i}}\right)$ and after $\left(\mathrm{w}_{\mathrm{f}}\right)$ impregnation in 1X PBS for three days. Swelling ratio was determined by the following equation: $\mathrm{Sw}=\left(\mathrm{w}_{\mathrm{f}}-\mathrm{w}_{\mathrm{i}}\right) / \mathrm{w}_{\mathrm{i}}$ 


\subsubsection{In Vitro Enzymatic Degradation}

Having determined scaffolds initial weight in $1 \times$ PBS, scaffolds were incubated at $37{ }^{\circ} \mathrm{C}$ in a solution of pullulanase (Sigma, E2412) and dextranase (Sigma, D0443) diluted, respectively, 1.5/10 and $0.75 / 10$ in $1 \times$ PBS. Every 5 min scaffolds were retrieved and weighed after removing the excess of liquid using filter papers. Scaffolds degradation was followed overtime until $100 \%$ mass loss. Samples were run in triplicate and results were expressed as mean values \pm SD.

\subsubsection{Dynamic Mechanical Testing}

Hydrogels of $25 \mathrm{~mm}$ in diameter and $1 \mathrm{~cm}$ height were prepared and hydrated in PBS for two weeks before analysis on Discovery HR2 (TA Instruments, Guyancourt, France) rheometer. Shear stress measurements were performed in PBS under oscillation mode using $25 \mathrm{~mm}$ aluminum plate geometries fitted with sandpaper, grit size 600, to avoid sample slippage during measurement. Viscoelastic linear domains were determined by an amplitude sweep between $0.01 \%$ to $10 \%$ strain with a constant frequency of $1 \mathrm{~Hz}$ at $25{ }^{\circ} \mathrm{C}$. To ensure minimal compression, normal force was kept constant at $0.3+/-0.1 \mathrm{~N}$. Samples were run in triplicate and results expressed as mean values \pm SD.

\subsection{Characterization of Scaffolds Microstructure}

The microstructure of the freeze-dried scaffolds was analyzed using Scanning Electron Microscopy (SEM). Scaffolds were cut vertically using a razor blade and glued to sample holders to observe the inner structure in a SEM JSM-IT100 InTouchScope ${ }^{\mathrm{TM}}$ (Jeol, Croissy, France)under low vacuum mode (40 Pa) at a $20-\mathrm{kV}$ acceleration voltage.

For porosity analysis in wet state, scaffolds containing FITC-Dextran were hydrated in $1 \times$ PBS and analyzed using 2-photon Leica SP8 microscope fitted with a HCX IRAPO L 25X objective (CRI-U1149 Imaging facility). Confocal slices ( $3 \mu \mathrm{m}$ deep) were imaged over about 150-200 $\mu \mathrm{m}$ in the scaffold depth with biphoton excitation at $750 \mathrm{~nm}$. A macro was written specifically to determine polymer and pore volumes in 3D Stacks using FIJI freeware. Briefly, the images intensities were normalized in the gel depth before applying an intensity threshold to obtain a binary image. The plugging 3D object counter [78] was used to detect objects corresponding to the pores in the scaffolds and the total volume and pores volumes were calculated and compiled. Total volume analyzed per scaffold was at least $0.15 \mathrm{~mm}^{3}$, with at least six scaffolds analyzed for each condition.

\subsection{Cell Culture and Loading into 3D Scaffolds}

HepG2 cells (Human hepatocellular carcinoma) were obtained from ATCC ${ }^{\circledR}\left(\mathrm{HB} 8065^{\mathrm{TM}}\right)$ and cultured in Dulbecco's modified Eagle's Medium DMEM $4.5 \mathrm{~g} / \mathrm{L}$ glucose supplemented with 10\% Fetal Bovine Serum and 1\% antibiotic-antimycotic (Sigma, France). The scaffolds were sterilized under UV light for $30 \mathrm{~min}$ before cell culture. Cell loading into scaffolds was performed using syringe-induced vacuum, adapted from [79]. Briefly, all scaffolds were introduced in a syringe along with a cell suspension; the plunger was introduced and the syringe tip was closed using a 3-way valve. Vacuum was induced by moving the plunger of about $3 \mathrm{~cm}$ up and down until the scaffold were fully impregnated, i.e., when they become transparent. Maximum cell loading efficiency was determined beforehand and a seeding density of approximately 100,000 cells per scaffold, i.e., $1428 \mathrm{cells} / \mu \mathrm{L}$, was chosen. Scaffolds were placed in 24-well plates with $1 \mathrm{~mL}$ DMEM.

\subsection{Cell Clusters Size and Shape Analysis}

Cellularized scaffolds were fixed with paraformaldehyde $4 \%$ for $1 \mathrm{~h}$ at room temperature, rinsed three times with $1 \times$ PBS, permeabilized with $0.1 \%$ Triton X100 for $1 \mathrm{~h}$ followed by incubation in a solution of Phalloidin (Phalloidin-TRITC 1/200, Sigma) and DAPI (Sigma, $1 \mu \mathrm{g} / \mathrm{mL}$ ) for $1 \mathrm{~h}$ at room temperature. 3D stacks were obtained using an inverted Zeiss LSM 780 confocal microscope fitted with a 10× objective (CRI-U1149 Imaging facility) over up to $400 \mu \mathrm{m}$ in the scaffold depth to analyze cell 
clusters size and shape. Images were reconstructed in 3D using Imaris software and a semi-automatic analysis allowed the detection of objects corresponding to the cell clusters. A background intensity threshold and minimal exclusion size of about one cell were set manually, individual items too close to be separated automatically were split manually and filters were applied to remove objects not entirely in the field of view. The volumes of cell clusters were then evaluated automatically for at least three samples per condition and a total of more than 150 cell clusters were analyzed.

\subsection{Cell Viability Assay}

\subsubsection{Live-Dead Analysis}

Live-dead analysis was performed at day one, four and seven to analyze the viability in the depth of the scaffolds. Calcein AM (Invitrogen, Les Ulis France) and Ethidium homodimer (Molecular Probes $\left.^{\mathrm{TM}}\right)$, were diluted in culture medium at $1 / 500$ and 1/200 ratios, respectively, and incubated with the cellularized scaffolds for $1 \mathrm{~h}$. After rinsing twice with $1 \times$ PBS, imaging was performed using Zeiss LSM 780 confocal microscope (CRI-U1149 Imaging facility) over about $300 \mu \mathrm{m}$ in the depth of the scaffold. The percentage of live and dead cells was determined in the gel depth. Briefly, cells were counted manually on $3 \mu \mathrm{m}$ deep confocal slices every $30 \mu \mathrm{m}$ on at least five different samples for each condition.

\subsubsection{Resazurin Assay}

Metabolic activity quantification was performed at day one, four and seven using the In Vitro Toxicology Assay Kit (MTT based, Sigma-Aldrich France). Seeded scaffolds were transferred to a 48-well plate and incubated with $0.5 \mathrm{~mL}$ of resazurin for $2.5 \mathrm{~h}$ at $37^{\circ} \mathrm{C}$. Fluorescence of the resulting solution was measured Using Infinite M200 Pro, TECAN ${ }^{\circledR}$ plate reader (560Ex/590Em). All samples were run in triplicate in triplicate in three different experiments.

\subsection{Cell Functionality Analysis}

\subsubsection{Albumin Secretion}

Albumin secretion in cell culture medium was determined overtime by an ELISA assay (Thermo Scientific ${ }^{\mathrm{TM}}$ ) according to the manufacturer's recommendations. Standards and samples were incubated in the Anti-Human Albumin Precoated 96-well Strip Plate for $2.5 \mathrm{~h}$ at room temperature and washed four times before the addition of a biotinylated antibody. After rinsing, the streptavidin-HRP reagent was incubated. Finally, TMB substrate was added and the absorbance was measured at 450 and $550 \mathrm{~nm}$ using the Infinite M200 Pro, TECAN ${ }^{\circledR}$ plate reader (Tecan, Männedorf, Switzerland). All samples were run in triplicate.

\subsubsection{CYP3A4 Activity}

Cytochrome P4503A4 (CYP3A4) activity was analyzed using P450-Glo ${ }^{\text {TM }}$ CYP3A4 Assay (Promega). Briefly, a pro-luciferin substrate was added to the cell culture medium and incubated for $1 \mathrm{~h}$ at $37^{\circ} \mathrm{C}$. Aliquots of supernatants were collected and incubated with the luminogenic detection reagent before luminescence reading using TECAN ${ }^{\circledR}$ plate reader. All samples were run in triplicate.

\subsubsection{Cell Number Assessment}

To normalize cell activity to number of cells, total protein content was determined using Micro $\mathrm{BCA}^{\mathrm{TM}}$ Protein Assay Kit (Thermo Scientific ${ }^{\mathrm{TM}}$ ). Hydrogels were digested using pullulanase and dextranase diluted in $1 \mathrm{X}$ PBS (respectively $1 / 10$ and $1 / 20$ ) for about $40 \mathrm{~min}$ at $37^{\circ} \mathrm{C}$. Cells were rinsed twice with 1X PBS and lysed in $350 \mu$ of cold TRIS-EDTA lysis buffer (Invitrogen ${ }^{\mathrm{TM}}$ T11493) and homogenized using 25-G needles. Cell numbers were calculated thanks to a standard curve of known cells concentrations and used to normalize albumin production and CYP3A4 activity. 


\subsubsection{Albumin and HNF4 $\alpha$ Staining}

Scaffolds containing HepG2 cell clusters were fixed after seven days in paraformaldehyde $4 \%$ and rinsed before blocking and permeabilization in $1 \%$ BSA $0,1 \%$ Triton for $3 \mathrm{~h}$ at room temperature. Anti-albumin primary antibody (Tebu-bio Cedarlane, 007CL2513A, 1/200) was incubated for $24 \mathrm{~h}$ at $4{ }^{\circ} \mathrm{C}$ in blocking solution, followed by extensive rinsing. Anti-NHF4 $\alpha$ antibody (Ozyme Atlas, HPA004712, 1/150) was then incubated for $3 \mathrm{~h}$ at room temperature and finally after rinsing the secondary antibodies, AlexaFluor 555 anti-mouse Alexa Fluor 647 anti-rabbit (Invitrogen ${ }^{\mathrm{TM}}, 1 / 200$ ) were applied for $1.5 \mathrm{~h}$ at room temperature. Samples were observed using Zeiss LSM 780 confocal microscope fitted with a 10× objective (CRI-U1149 Imaging facility).

\subsection{Acetaminophen Dose-Toxicity Analysis}

Acetaminophen dose response was analyzed in the 3D scaffolds at day seven. HepG2 cells were treated for $24 \mathrm{~h}$ with increasing concentrations of acetaminophen (Sigma). As acetaminophen is not fully solubilized above $100 \mathrm{mM}, 200 \mathrm{mM}$ acetaminophen solutions were prepared separately for each well for reproducibility purposes. Cell viability was quantified using resazurin-based metabolic activity $\left(2 \mathrm{~h}\right.$ incubation at $\left.37^{\circ} \mathrm{C}\right)$. Fluorescence was measured using Infinite M200 Pro, TECAN ${ }^{\circledR}$ plate reader $(560 \mathrm{Ex} / 590 \mathrm{Em})$. Data were expressed as a percentage of unstimulated cells viability. Fits of cell viability concatenated data were drawn using Origin software to determine $\mathrm{EC}_{50}$ (half maximal effective concentration). Experiments were done in triplicate with 8-16 samples per experiment.

\subsection{Statistical Analysis}

All experiments were carried out at least in triplicate and statistical analysis was performed using Student's $t$-test for all analysis except for viability and functionality analysis overtime where ANOVA with Tukey's post-test was used. Statistical significance was indicated as ${ }^{*} p<0.05,{ }^{* *} p<0.01$, $* * * p<0.001$.

\section{Conclusions}

The aim of this project was to produce viable and functional hepatic constructs within polysaccharide-based scaffolds with different structures, and to determine whether these structures could affect cell morphology, viability and functionality. Pullulan-dextran hydrogels devoid of any components of human or animal origin were prepared easily in the absence of organic solvent using pharmaceutical-grade polysaccharides and a process that can be translated in industry to produce GMP scaffolds. Our results showed that different porosities can be created depending on the porogen. Cell loading efficiency was inversely proportional to porosity and hepatocytes formed constructs that match with pore size and geometry. In small spherical pores, cells mostly condensed to form spherical cell clusters, whereas in large elongated pores, cells formed long and thin cell constructs. In all types of scaffolds, HepG2 cells were highly viable, proliferate for seven days and present characteristics of functional organoids such as albumin production, CYP3A4 activity and sensitivity to acetaminophen. Therefore, hepatic organoids in such a 3D microenvironment with adjustable properties can be adapted for in vitro drug screening, in vivo implantations and extracorporeal devices.

Author Contributions: Conceptualization, M.-N.L. and D.L.; validation, M.-N.L., C.L.G., R.A.-L., N.E.S., S.L., and T.S.-Y.; formal analysis, M.-N.L.; investigation, M.-N.L., C.L.G., R.A.-L., N.E.S., S.L.; resources, D.L.; writing-original draft preparation, M.-N.L.; writing—review and editing, M.-N.L., D.L., C.L.G., T.S.-Y., R.A.-L., S.L.; visualization, M.-N.L.; project administration, D.L.; funding acquisition, D.L. All authors have read and agreed to the published version of the manuscript.

Funding: This research was funded by "Recherche Hospitalo-universitaire" Innovations for Liver Tissue Engineering (RHU iLite), grant number ANR-16-RHUS-0005. Works from the Laboratory U1148 are supported by Inserm, Université Sorbonne Paris Nord, and Université de Paris.

Acknowledgments: We acknowledge Samira Bennada of the CRI U1149 Imaging facility for technical support, Anne Dubart-Kupperschmitt and Antonietta Messina for fruitful discussions. 
Conflicts of Interest: D.L. has shares in SILTISS company that acquired from INSERM four patents related to the production of polysaccharide scaffolds for tissue regeneration.

\section{Abbreviations}

$\begin{array}{ll}\mathrm{NaCl} & \text { Sodium Chloride } \\ \mathrm{Na}_{2} \mathrm{CO}_{3} & \text { Sodium carbonate } \\ \text { PBS } & \text { Phosphate Buffer Saline } \\ \text { SEM } & \text { Scanning Electron Microscopy } \\ \text { STMP } & \text { Sodium Trimetaphosphate } \\ \text { CYP3A4 } & \text { Cytochrome P4503A4 } \\ \text { EC }_{50} & \text { Half Maximal Effective Concentration }\end{array}$

\section{References}

1. Asrani, S.K.; Devarbhavi, H.; Eaton, J.; Kamath, P.S. Burden of liver diseases in the world. J. Hepatol. 2019, 70, 151-171. [CrossRef]

2. Ananthanarayanan, A.; Narmada, B.C.; Mo, X.; McMillian, M.; Yu, H. Purpose-driven biomaterials research in liver-tissue engineering. Trends Biotechnol. 2011, 29, 110-118. [CrossRef] [PubMed]

3. Takebe, T.; Sekine, K.; Enomura, M.; Koike, H.; Kimura, M.; Ogaeri, T.; Zhang, R.-R.; Ueno, Y.; Zheng, Y.-W.; Koike, N.; et al. Vascularized and functional human liver from an iPSC-derived organ bud transplant. Nature 2013, 499, 481-484. [CrossRef] [PubMed]

4. Takebe, T.; Sekine, K.; Kimura, M.; Yoshizawa, E.; Ayano, S.; Koido, M.; Funayama, S.; Nakanishi, N.; Hisai, T.; Kobayashi, T.; et al. Massive and Reproducible Production of Liver Buds Entirely from Human Pluripotent Stem Cells. Cell Rep. 2017, 21, 2661-2670. [CrossRef] [PubMed]

5. Legallais, C.; Kim, D.; Mihaila, S.M.; Mihajlovic, M.; Figliuzzi, M.; Bonandrini, B.; Salerno, S.; Yousef Yengej, F.A.; Rookmaaker, M.B.; Sanchez Romero, N.; et al. Bioengineering Organs for Blood Detoxification. Adv. Healthc. Mater. 2018, 7, e1800430. [CrossRef] [PubMed]

6. Shah, S.B.; Singh, A. Cellular self-assembly and biomaterials-based organoid models of development and diseases. Acta Biomater. 2017, 53, 29-45. [CrossRef] [PubMed]

7. Huh, D.; Hamilton, G.A.; Ingber, D.E. From 3D cell culture to organs-on-chips. Trends Cell Biol. 2011, 21, 745-754. [CrossRef]

8. Astashkina, A.; Grainger, D.W. Critical analysis of 3-D organoid in vitro cell culture models for high-throughput drug candidate toxicity assessments. Adv. Drug Deliv. Rev. 2014, 69, 1-18. [CrossRef]

9. Vasanthan, K.S.; Subramanian, A.; Krishnan, U.M.; Sethuraman, S. Role of biomaterials, therapeutic molecules and cells for hepatic tissue engineering. Biotechnol. Adv. 2012, 30, 742-752. [CrossRef]

10. Wang, B.; Jakus, A.E.; Baptista, P.M.; Soker, S.; Soto-Gutierrez, A.; Abecassis, M.M.; Shah, R.N.; Wertheim, J.A. Functional Maturation of Induced Pluripotent Stem Cell Hepatocytes in Extracellular Matrix-A Comparative Analysis of Bioartificial Liver Microenvironments. STEM CELLS Transl. Med. 2016, 5, 1257-1267. [CrossRef]

11. Van Grunsven, L.A. 3D in vitro models of liver fibrosis. Adv. Drug Deliv. Rev. 2017, 121, 133-146. [CrossRef] [PubMed]

12. Selden, C.; Bundy, J.; Erro, E.; Puschmann, E.; Miller, M.; Kahn, D.; Hodgson, H.; Fuller, B.; Gonzalez-Molina, J.; Le Lay, A.; et al. A clinical-scale BioArtificial Liver, developed for GMP, improved clinical parameters of liver function in porcine liver failure. Sci. Rep. 2017, 7, 14518. [CrossRef] [PubMed]

13. Stevens, K.R.; Scull, M.A.; Ramanan, V.; Fortin, C.L.; Chaturvedi, R.R.; Knouse, K.A.; Xiao, J.W.; Fung, C.; Mirabella, T.; Chen, A.X.; et al. In situ expansion of engineered human liver tissue in a mouse model of chronic liver disease. Sci. Transl. Med. 2017, 9, eaah5505. [CrossRef] [PubMed]

14. Coward, S.M.; Legallais, C.; David, B.; Thomas, M.; Foo, Y.; Mavri-Damelin, D.; Hodgson, H.J.; Selden, C. Alginate-encapsulated HepG2 Cells in a Fluidized Bed Bioreactor Maintain Function in Human Liver Failure Plasma. Artif. Organs 2009, 33, 1117-1126. [CrossRef] [PubMed]

15. Willemse, J.; Lieshout, R.; van der Laan, L.J.W.; Verstegen, M.M.A. From organoids to organs: Bioengineering liver grafts from hepatic stem cells and matrix. Best Pract. Res. Clin. Gastroenterol. 2017, 31, 151-159. [CrossRef] 
16. Lee, H.; Han, W.; Kim, H.; Ha, D.-H.; Jang, J.; Kim, B.S.; Cho, D.-W. Development of Liver Decellularized Extracellular Matrix Bioink for Three-Dimensional Cell Printing-Based Liver Tissue Engineering. Biomacromolecules 2017, 18, 1229-1237. [CrossRef]

17. Lewis, P.L.; Green, R.M.; Shah, R.N. 3D-printed gelatin scaffolds of differing pore geometry modulate hepatocyte function and gene expression. Acta Biomater. 2018, 69, 63-70. [CrossRef]

18. Mehta, G.; Hsiao, A.Y.; Ingram, M.; Luker, G.D.; Takayama, S. Opportunities and challenges for use of tumor spheroids as models to test drug delivery and efficacy. J. Control. Release 2012, 164, 192-204. [CrossRef]

19. Moshksayan, K.; Kashaninejad, N.; Warkiani, M.E.; Lock, J.G.; Moghadas, H.; Firoozabadi, B.; Saidi, M.S.; Nguyen, N.-T. Spheroids-on-a-chip: Recent advances and design considerations in microfluidic platforms for spheroid formation and culture. Sens. Actuators B Chem. 2018, 263, 151-176. [CrossRef]

20. Underhill, G.H.; Khetani, S.R. Bioengineered Liver Models for Drug Testing and Cell Differentiation Studies. Cell. Mol. Gastroenterol. Hepatol. 2018, 5, 426-439.e421. [CrossRef]

21. Dunn, J.C.Y.; Yarmush, M.L.; Koebe, H.G.; Tompkins, R.G. Hepatocyte Function and Extracellular-Matrix Geometry-Long-Term Culture in a Sandwich Configuration. FASEB J. 1989, 3, 174-177. [CrossRef]

22. Lu, Y.; Zhang, G.; Shen, C.; Uygun, K.; Yarmush, M.L.; Meng, Q. A novel 3D liver organoid system for elucidation of hepatic glucose metabolism. Biotechnol. Bioeng. 2012, 109, 595-604. [CrossRef] [PubMed]

23. Leite, S.B.; Roosens, T.; El Taghdouini, A.; Mannaerts, I.; Smout, A.J.; Najimi, M.; Sokal, E.; Noor, F.; Chesne, C.; van Grunsven, L.A. Novel human hepatic organoid model enables testing of drug-induced liver fibrosis in vitro. Biomaterials 2016, 78, 1-10. [CrossRef] [PubMed]

24. Sendi, H.; Mead, I.; Wan, M.; Mehrab-Mohseni, M.; Koch, K.; Atala, A.; Bonkovsky, H.L.; Bishop, C.E. miR-122 inhibition in a human liver organoid model leads to liver inflammation, necrosis, steatofibrosis and dysregulated insulin signaling. PLOS ONE 2018, 13, e0200847. [CrossRef]

25. Manley, P.; Lelkes, P.I. A novel real-time system to monitor cell aggregation and trajectories in rotating wall vessel bioreactors. J. Biotechnol. 2006, 125, 416-424. [CrossRef] [PubMed]

26. Glicklis, R.; Merchuk, J.C.; Cohen, S. Modeling mass transfer in hepatocyte spheroids via cell viability, spheroid size, and hepatocellular functions. Biotechnol. Bioeng. 2004, 86, 672-680. [CrossRef]

27. Miyamoto, Y.; Ikeuchi, M.; Noguchi, H.; Yagi, T.; Hayashi, S. Spheroid Formation and Evaluation of Hepatic Cells in a Three-Dimensional Culture Device. Cell Med. 2015, 8, 47-56. [CrossRef]

28. Wong, S.F.; No, D.Y.; Choi, Y.Y.; Kim, D.S.; Chung, B.G.; Lee, S.-H. Concave microwell based size-controllable hepatosphere as a three-dimensional liver tissue model. Biomaterials 2011, 32, 8087-8096. [CrossRef]

29. Gevaert, E.; Billiet, T.; Declercq, H.; Dubruel, P.; Cornelissen, R. Galactose-Functionalized Gelatin Hydrogels Improve the Functionality of Encapsulated Hepg2 Cells. Macromol. Biosci. 2014, 14, 419-427. [CrossRef]

30. Au, S.H.; Chamberlain, M.D.; Mahesh, S.; Sefton, M.V.; Wheeler, A.R. Hepatic organoids for microfluidic drug screening. Lab Chip 2014, 14, 3290-3299. [CrossRef]

31. Lim, W.; Park, S. A Microfluidic Spheroid Culture Device with a Concentration Gradient Generator for High-Throughput Screening of Drug Efficacy. Molecules 2018, 23, 3355. [CrossRef]

32. Mattei, G.; Ahluwalia, A. Sample, testing and analysis variables affecting liver mechanical properties: A review. Acta Biomater. 2016, 45, 60-71. [CrossRef] [PubMed]

33. Dvir-Ginzberg, M.; Gamlieli-Bonshtein, I.; Agbaria, R.; Cohen, S. Liver tissue engineering within alginate scaffolds: Effects of cell-seeding density on hepatocyte viability, morphology, and function. Tissue Eng. 2003, 9, 757-766. [CrossRef] [PubMed]

34. Tripathi, A.; Melo, J.S. Preparation of a sponge-like biocomposite agarose-chitosan scaffold with primary hepatocytes for establishing an in vitro 3D liver tissue model. RSC Adv. 2015, 5, 30701-30710. [CrossRef]

35. Garnier, D.; Li, R.; Delbos, F.; Fourrier, A.; Collet, C.; Guguen-Guillouzo, C.; Chesné, C.; Nguyen, T.H. Expansion of human primary hepatocytes in vitro through their amplification as liver progenitors in a $3 \mathrm{D}$ organoid system. Sci. Rep. 2018, 8. [CrossRef] [PubMed]

36. Takai, A.; Fako, V.; Dang, H.; Forgues, M.; Yu, Z.; Budhu, A.; Wang, X.W. Three-dimensional Organotypic Culture Models of Human Hepatocellular Carcinoma. Sci. Rep. 2016, 6. [CrossRef]

37. Soto-Gutierrez, A.; Navarro-Alvarez, N.; Yagi, H.; Nahmias, Y.; Yarmush, M.L.; Kobayashi, N. Engineering of an Hepatic Organoid to Develop Liver Assist Devices. Cell Transplant. 2010, 19, 815-822. [CrossRef]

38. Shteyer, E.; Ya'acov, A.B.; Zolotaryova, L.; Sinai, A.; Lichtenstein, Y.; Pappo, O.; Kryukov, O.; Elkayam, T.; Cohen, S.; Ilan, Y. Reduced liver cell death using an alginate scaffold bandage: A novel approach for liver reconstruction after extended partial hepatectomy. Acta Biomater. 2014, 10, 3209-3216. [CrossRef] 
39. Chaouat, M.; Le Visage, C.; Autissier, A.; Chaubet, F.; Letourneur, D. The evaluation of a small-diameter polysaccharide-based arterial graft in rats. Biomaterials 2006, 27, 5546-5553. [CrossRef]

40. Autissier, A.; Visage, C.L.; Pouzet, C.; Chaubet, F.; Letourneur, D. Fabrication of porous polysaccharide-based scaffolds using a combined freeze-drying/cross-linking process. Acta Biomater. 2010, 6, 3640-3648. [CrossRef]

41. Autissier, A.; Chaubet, F.; Letourneur, D.; Le Visage, C. Preparing porous scaffold for tissue engineering, 3 dimensional (3D) cell culture or cell delivery for therapeutic use, by preparing an alkaline aqueous solution, freezing the aqueous solution, and sublimating the frozen solution. U.S. patent No. 20150246163, 9 March 2015.

42. Letourneur, D.; Le Visage, C. Preparing porous scaffold for tissue engineering, cell culture and cell delivery by preparing alkaline aqueous solution, transforming solution into hydrogel, submerging hydrogel into aqueous solution and washing the obtained porous scaffold. U.S. patent No. 20200016294, 16 January 2020.

43. Fricain, J.C.; Schlaubitz, S.; Le Visage, C.; Arnault, I.; Derkaoui, S.M.; Siadous, R.; Catros, S.; Lalande, C.; Bareille, R.; Renard, M.; et al. A nano-hydroxyapatite-Pullulan/dextran polysaccharide composite macroporous material for bone tissue engineering. Biomaterials 2013, 34, 2947-2959. [CrossRef] [PubMed]

44. Guerrero, J.; Catros, S.; Derkaoui, S.M.; Lalande, C.; Siadous, R.; Bareille, R.; Thébaud, N.; Bordenave, L.; Chassande, O.; Le Visage, C.; et al. Cell interactions between human progenitor-derived endothelial cells and human mesenchymal stem cells in a three-dimensional macroporous polysaccharide-based scaffold promote osteogenesis. Acta Biomater. 2013, 9, 8200-8213. [CrossRef] [PubMed]

45. Lavergne, M.; Derkaoui, M.; Delmau, C.; Letourneur, D.; Uzan, G.; Le Visage, C. Porous Polysaccharide-Based Scaffolds for Human Endothelial Progenitor Cells. Macromol. Biosci. 2012, 12, 901-910. [CrossRef] [PubMed]

46. Lanouar, S.; Aid-Launais, R.; Oliveira, A.; Bidault, L.; Closs, B.; Labour, M.-N.; Letourneur, D. Effect of cross-linking on the physicochemical and in vitro properties of pullulan/dextran microbeads. J. Mater. Sci. Mater. Med. 2018, 29. [CrossRef] [PubMed]

47. Abed, A.; Assoul, N.; Ba, M.; Derkaoui, S.M.; Portes, P.; Louedec, L.; Flaud, P.; Bataille, I.; Letourneur, D.; Meddahi-Pellé, A. Influence of polysaccharide composition on the biocompatibility of pullulan/dextran-based hydrogels. J. Biomed. Mater. Res. Part A 2011, 96A, 535-542. [CrossRef]

48. Capone, S.H.; Dufresne, M.; Rechel, M.; Fleury, M.-J.; Salsac, A.-V.; Paullier, P.; Daujat-Chavanieu, M.; Legallais, C. Impact of alginate composition: From bead mechanical properties to encapsulated HepG2/C3A cell activities for in vivo implantation. PLoS ONE 2013, 8, e62032. [CrossRef]

49. Glicklis, R.; Shapiro, L.; Agbaria, R.; Merchuk, J.C.; Cohen, S. Hepatocyte behavior within three-dimensional porous alginate scaffolds. Biotechnol. Bioeng. 2000, 67, 344-353. [CrossRef]

50. Luckert, C.; Schulz, C.; Lehmann, N.; Thomas, M.; Hofmann, U.; Hammad, S.; Hengstler, J.G.; Braeuning, A.; Lampen, A.; Hessel, S. Comparative analysis of 3D culture methods on human HepG2 cells. Arch. Toxicol. 2017, 91, 393-406. [CrossRef]

51. Ng, S.; Han, R.; Chang, S.; Ni, J.; Hunziker, W.; Goryachev, A.B.; Ong, S.H.; Yu, H. Improved hepatocyte excretory function by immediate presentation of polarity cues. Tissue Eng. 2006, 12, 2181-2191. [CrossRef]

52. Nishikawa, T.; Tanaka, Y.; Kusamori, K.; Mizuno, N.; Mizukami, Y.; Ogino, Y.; Shimizu, K.; Konishi, S.; Takahashi, Y.; Takakura, Y.; et al. Using size-controlled multicellular spheroids of murine adenocarcinoma cells to efficiently establish pulmonary tumors in mice. Biotechnol. J. 2017, 12, 1600513. [CrossRef]

53. Nishikawa, T.; Tanaka, Y.; Nishikawa, M.; Ogino, Y.; Kusamori, K.; Mizuno, N.; Mizukami, Y.; Shimizu, K.; Konishi, S.; Takahashi, Y.; et al. Optimization of Albumin Secretion and Metabolic Activity of Cytochrome P450 1A1 of Human Hepatoblastoma HepG2 Cells in Multicellular Spheroids by Controlling Spheroid Size. Biol. Pharm. Bull. 2017, 40, 334-338. [CrossRef] [PubMed]

54. Boyer, J.L. Bile formation and secretion. Compr. Physiol. 2013, 3, 1035-1078. [CrossRef] [PubMed]

55. Théard, D.; Steiner, M.; Kalicharan, D.; Hoekstra, D.; van Ijzendoorn, S.C.D.; Mostov, K. Cell Polarity Development and Protein Trafficking in Hepatocytes Lacking E-Cadherin/ $\beta$-Catenin-based Adherens Junctions. Mol. Biol. Cell 2007, 18, 2313-2321. [CrossRef] [PubMed]

56. Tsukada, N.; Ackerley, C.A.; Phillips, M.J. The structure and organization of the bile canalicular cytoskeleton with special reference to actin and actin-binding proteins. Hepatology 1995, 21, 1106-1113. [CrossRef] [PubMed]

57. Yumoto, A.U.; Watanabe, S.; Hirose, M.; Kitamura, T.; Yamaguchi, Y.; Sato, N. Structural and functional features of bile canaliculi in adult rat hepatocyte spheroids. Liver 1996, 16, 61-66. [CrossRef]

58. Zhang, Y.; Wang, C.; Jiang, W.; Zuo, W.; Han, G. Influence of Stage Cooling Method on Pore Architecture of Biomimetic Alginate Scaffolds. Sci. Rep. 2017, 7. [CrossRef] 
59. Grenier, J.; Duval, H.; Barou, F.; Lv, P.; David, B.; Letourneur, D. Mechanisms of pore formation in hydrogel scaffolds textured by freeze-drying. Acta Biomater. 2019, 94, 195-203. [CrossRef]

60. Purnama, A.; Aid-Launais, R.; Haddad, O.; Maire, M.; Mantovani, D.; Letourneur, D.; Hlawaty, H.; Le Visage, C. Fucoidan in a 3D scaffold interacts with vascular endothelial growth factor and promotes neovascularization in mice. Drug Deliv. Transl. Res. 2013, 5, 187-197. [CrossRef]

61. Wang, L.; Wu, Y.-K.; Ai, F.-F.; Fan, J.; Xia, Z.-P.; Liu, Y. Hierarchical Porous Polyamide 6 by Solution Foaming: Synthesis, Characterization and Properties. Polymers 2018, 10, 1310. [CrossRef]

62. Dulong, V.; Forbice, R.; Condamine, E.; Le Cerf, D.; Picton, L. Pullulan-STMP hydrogels: A way to correlate crosslinking mechanism, structure and physicochemical properties. Polym. Bull. 2011, 67, 455-466. [CrossRef]

63. Lack, S.; Dulong, V.; Picton, L.; Cerf, D.L.; Condamine, E. High-resolution nuclear magnetic resonance spectroscopy studies of polysaccharides crosslinked by sodium trimetaphosphate: A proposal for the reaction mechanism. Carbohydr. Res. 2007, 342, 943-953. [CrossRef]

64. Brassard, J.A.; Lutolf, M.P. Engineering Stem Cell Self-organization to Build Better Organoids. Cell Stem Cell 2019, 24, 860-876. [CrossRef] [PubMed]

65. Kourouklis, A.P.; Kaylan, K.B.; Underhill, G.H. Substrate stiffness and matrix composition coordinately control the differentiation of liver progenitor cells. Biomaterials 2016, 99, 82-94. [CrossRef] [PubMed]

66. Ramaiahgari, S.C.; den Braver, M.W.; Herpers, B.; Terpstra, V.; Commandeur, J.N.M.; van de Water, B.; Price, L.S. A 3D in vitro model of differentiated HepG2 cell spheroids with improved liver-like properties for repeated dose high-throughput toxicity studies. Arch. Toxicol. 2014, 88, 1083-1095. [CrossRef] [PubMed]

67. Anada, T.; Fukuda, J.; Sai, Y.; Suzuki, O. An oxygen-permeable spheroid culture system for the prevention of central hypoxia and necrosis of spheroids. Biomaterials 2012, 33, 8430-8441. [CrossRef] [PubMed]

68. Curcio, E.; Salerno, S.; Barbieri, G.; De Bartolo, L.; Drioli, E.; Bader, A. Mass transfer and metabolic reactions in hepatocyte spheroids cultured in rotating wall gas-permeable membrane system. Biomaterials 2007, 28, 5487-5497. [CrossRef]

69. Pingitore, P.; Sasidharan, K.; Ekstrand, M.; Prill, S.; Lindén, D.; Romeo, S. Human Multilineage 3D Spheroids as a Model of Liver Steatosis and Fibrosis. Int. J. Mol. Sci. 2019, 20, 1629. [CrossRef]

70. McMurtrey, R.J. Analytic Models of Oxygen and Nutrient Diffusion, Metabolism Dynamics, and Architecture Optimization in Three-Dimensional Tissue Constructs with Applications and Insights in Cerebral Organoids. Tissue Eng. Part C Methods 2016, 22, 221-249. [CrossRef]

71. Ferrell, R.T.; Himmelblau, D.M. Diffusion coefficients of nitrogen and oxygen in water. J. Chem. Eng. Data 1967, 12, 111-115. [CrossRef]

72. Hulst, A.C.; Hens, H.J.H.; Buitelaar, R.M.; Tramper, J. Determination of the effective diffusion coefficient of oxygen in gel materials in relation to gel concentration. Biotechnol. Tech. 1989, 3, 199-204. [CrossRef]

73. Chatelin, S.; Oudry, J.; Perichon, N.; Sandrin, L.; Allemann, P.; Soler, L.; Willinger, R. In vivo liver tissue mechanical properties by Transient Elastography: Comparison with Dynamic Mechanical Analysis. Biorheology 2011, 48, 75-88. [CrossRef]

74. Liu, Z.; Bilston, L. On the viscoelastic character of liver tissue: Experiments and modelling of the linear behaviour. Biorheology 2000, 37, 191-201. [PubMed]

75. Marchesseau, S.; Heimann, T.; Chatelin, S.; Willinger, R.; Delingette, H. Fast porous visco-hyperelastic soft tissue model for surgery simulation: Application to liver surgery. Prog. Biophys. Mol. Biol. 2010, 103, 185-196. [CrossRef] [PubMed]

76. Guimaraes, C.F.; Gasperini, L.; Marques, A.P.; Reis, R.L. The stiffness of living tissues and its implications for tissue engineering. Nat. Rev. Mater. 2020. [CrossRef]

77. Available online: https://ansm.sante.fr/ (accessed on 18 April 2020).

78. Bolte, S.; Cordelieres, F.P. A guided tour into subcellular colocalization analysis in light microscopy. J. Microsc. 2006, 224, 213-232. [CrossRef] [PubMed]

79. Antunes, J.C.; Oliveira, J.M.; Reis, R.L.; Soria, J.M.; Gómez-Ribelles, J.L.; Mano, J.F. Novel poly(L-lactic acid)/hyaluronic acid macroporous hybrid scaffolds: Characterization and assessment of cytotoxicity. J. Biomed. Mater. Res. Part A 2010, 94, 856-869. [CrossRef]

(C) 2020 by the authors. Licensee MDPI, Basel, Switzerland. This article is an open access article distributed under the terms and conditions of the Creative Commons Attribution (CC BY) license (http://creativecommons.org/licenses/by/4.0/). 